\title{
Homogenization Experiments of Crystal-Rich Inclusions in Spodumene from Jiajika Lithium Deposit, China, under Elevated External Pressures in a Hydrothermal Diamond-Anvil Cell
}

\author{
Jiankang $\mathrm{Li}^{1}$ and I-Ming Chou ${ }^{2}$ \\ ${ }^{1}$ MLR Key Laboratory of Metallogeny and Mineral Assessment, Institute of Mineral Resources, Chinese Academy of Geological Sciences, \\ Beijing 100037, China \\ ${ }^{2}$ CAS Key Laboratory for Experimental Study under Deep-Sea Extreme Conditions, Institute of Deep-Sea Science and Engineering, \\ Chinese Academy of Sciences, Sanya, Hainan 572000, China
}

Correspondence should be addressed to Jiankang Li; li9968@126.com and I-Ming Chou; imchou@idsse.ac.cn

Received 11 June 2017; Accepted 10 September 2017; Published 14 November 2017

Academic Editor: Daniel E. Harlov

Copyright (C) 2017 Jiankang Li and I-Ming Chou. This is an open access article distributed under the Creative Commons Attribution License, which permits unrestricted use, distribution, and reproduction in any medium, provided the original work is properly cited.

\begin{abstract}
Extensive studies of the crystal-rich inclusions (CIs) hosted in minerals in pegmatite have resulted in substantially different models for the formation mechanism of the pegmatite. In order to evaluate these previously proposed formation mechanisms, the total homogenization processes of CIs hosted in spodumene from the Jiajika pegmatite deposit in Sichuan, China, were observed in situ under external $\mathrm{H}_{2} \mathrm{O}$ pressures in a new type of hydrothermal diamond-anvil cell (HDAC). The CIs in a spodumene chip were loaded in the sample chamber of HDAC with water, such that the CIs were under preset external $\mathrm{H}_{2} \mathrm{O}$ pressures during heating to avoid possible decrepitation. Our in situ observations showed that the crystals within the CIs were dissolved in carbonic-rich aqueous fluid during heating and that cristobalite was usually the first mineral being dissolved, followed by zabuyelite and silicate minerals until their total dissolution at temperatures between 500 and $720^{\circ} \mathrm{C}$. These observations indicated that the minerals within the CIs were daughter minerals crystallized from an entrapped carbonate- and silica-rich aqueous solution and therefore provided useful information for evaluating the formation models of granitic pegmatites.
\end{abstract}

\section{Introduction}

Crystal-rich inclusions (CIs) are a common and important type of fluid inclusion in granitic pegmatites, especially those rich in rare elements (e.g., $\mathrm{Li}, \mathrm{Be}, \mathrm{Nb}$, and $\mathrm{Ta}$ ) or gems $[1,2]$. For example, CIs were reported by London $[3,4]$ from the Tanco Li-Ta and Afghan gem pegmatites. Subsequently, CIs were also found in the Keketuohai, Kelumute, and Kuwei pegmatites located in Altay, Xinjiang, China [5-7], the Jiajika LiBe-Nb-Ta pegmatite deposit, western Sichuan, China [8], the Ehrenfriedersdorf Sn-W pegmatite deposit, Germany [9], the Orlovka amazonite granite, East Transbaikalia, Russia [10], and the Borborema Pegmatite Province, northeastern Brazil [11]. Currently, the origin of CIs is controversial and has resulted in substantially different understandings for the formation mechanisms behind pegmatites [12]. London [1317] regarded CIs as representative of a flux-rich hydrous melt boundary layer in his constitutional zone refining model. Thomas et al. $[10,11,18-20]$ thought that CIs indicated the occurrence of liquid immiscibility in the granitic magma during formation of the pegmatite. Anderson et al. [21, 22] suggested a secondary origin for CIs due to a reaction between spodumene and an aqueous-carbonic fluid. These different interpretations need to be reevaluated utilizing additional microthermometric studies of CIs. This study provides additional and mostly new information about the properties of CIs in order to facilitate our understanding regarding the formation of the host mineral and pegmatites in general.

The internal pressures of CIs increase significantly during heating, and they tend to decrepitate before reaching the total homogenization temperature when heated in a conventional heating stage under one atmosphere external pressure. To prevent decrepitation, some previous homogenization 

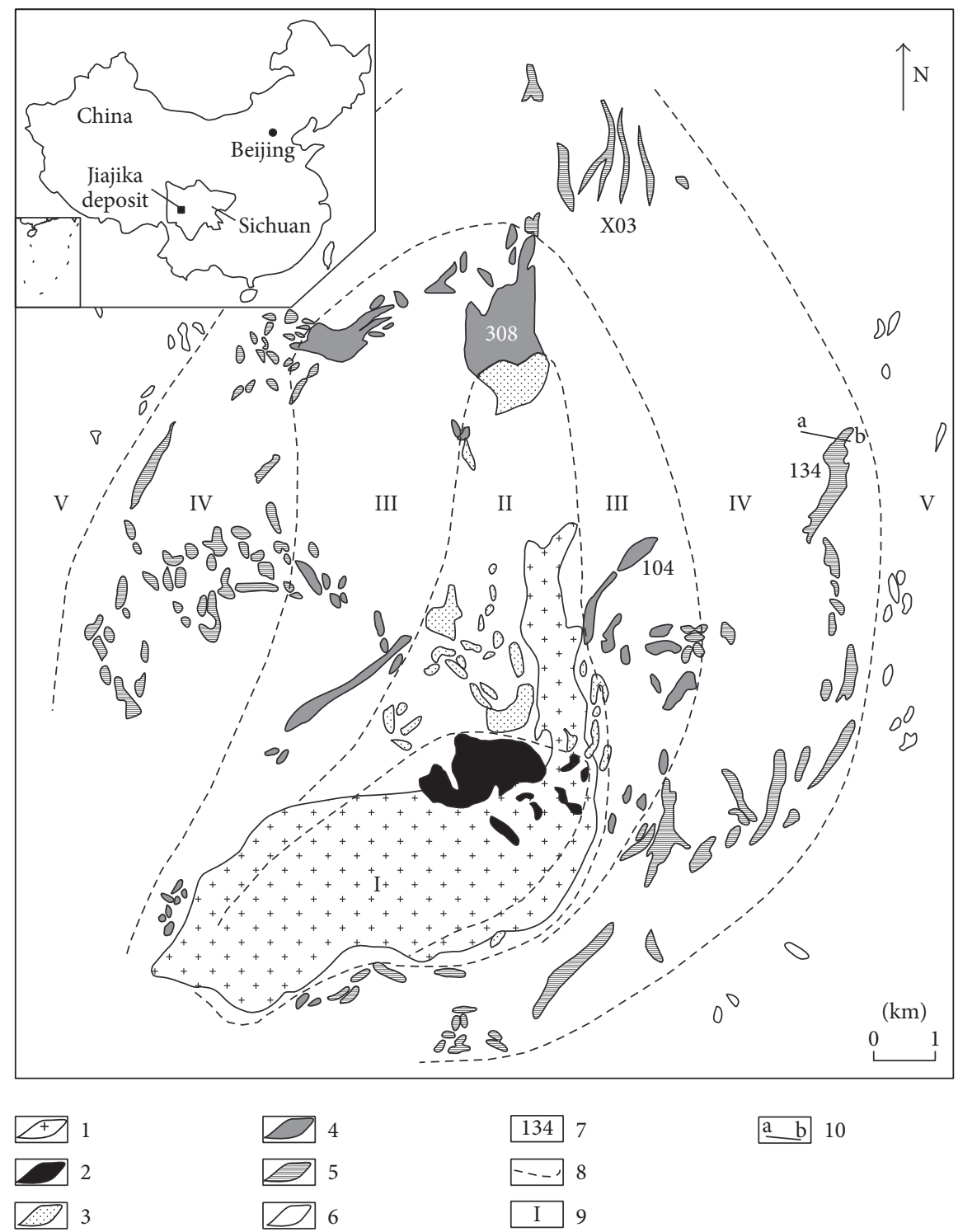

FIGURE 1: Distribution map of granitic pegmatites in Jiajika deposit, Sichuan Province. 1: two-mica granite; 2: microcline type pegmatite; 3 : microcline-albite type pegmatite; 4 : albite type pegmatite; 5 : albite-spodumene type pegmatite; 6 : albite-lepidolite type pegmatite; 7 : number of pegmatite dikes; 8: zoning line of different type of pegmatite; 9: zoning number of different type of pegmatite: I: microcline type pegmatite zone; II: microcline-albite type pegmatite zone; III: albite type pegmatite zone; IV: spodumene type pegmatite zone; V: lepidolite (muscovite) type pegmatite zone; 10: location of the cross section of number 134 pegmatite dike shown in Figure 2.

studies of CIs were performed under elevated external pressures in cold-sealed pressure vessels [3, 18-20]. The homogenization processes were then reconstructed based on observations of the quenched CI instead of in situ observations. As a consequence, the validity of these interpretations regarding the temperature and processes behind homogenization remains uncertain.

To remove this uncertainty, we performed homogenization experiments of CIs from the Jiajika pegmatite under elevated external pressures in a hydrothermal diamondanvil cell (HDAC). This allowed in situ observations of the homogenization processes in the CIs and provided essential information about their formation.

\section{Geological Features of Jiajika Pegmatite Deposit, China}

The Jiajika pegmatite in western Sichuan Province, China, is the largest mineral lithium deposit in Asia [23]. It consists of pegmatite dikes, which surround the granite body in both horizontal and vertical directions (Figure 1). The wall rocks of the two-mica granite and pegmatites are schists metamorphosed from early Triassic mudstones and sandstones. The main tectonic features that control distribution of the pegmatites are joints and fissures that formed before or during emplacement. The rocks that host the Jiajika granite underwent multistage metamorphism during magmatism, 


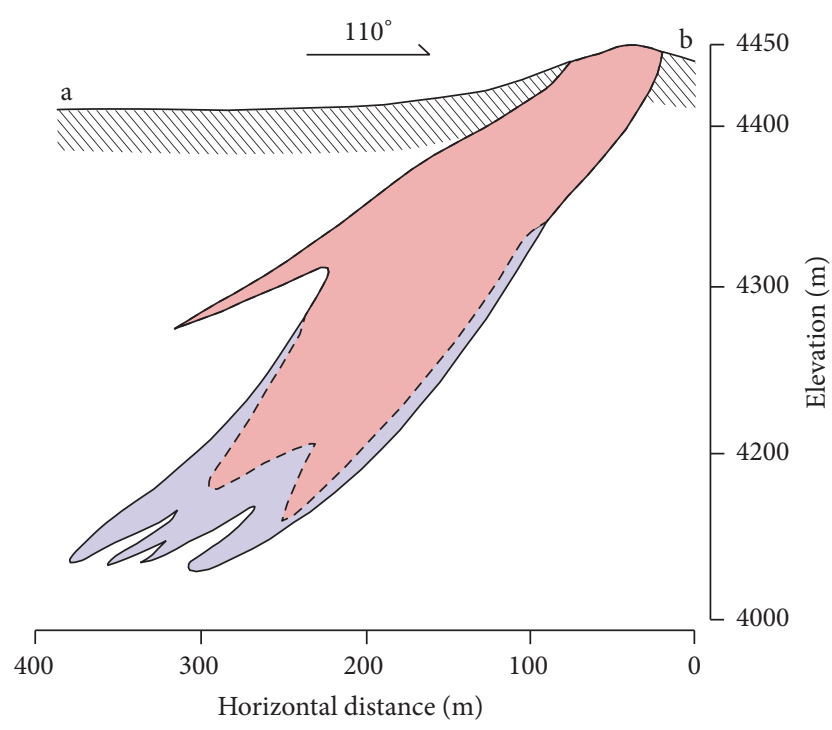

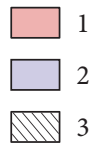

FIgURE 2: The cross section of number 134 pegmatite dike in Jiajika deposit. 1: spodumene zone, 2: albite zone, and 3: altered crystalline schist. The arrow direction of $110^{\circ}$ is the direction of cross section. The labels "a" and "b" correspond to the "a" and "b" shown in Figure 1 for the cross section.

which led to the development of the five distinct metamorphic zones that surround the granite (from inner to outer): diopside, staurolite, andalusite-staurolite, andalusite, and biotite zones. The total area of the metamorphic zones is about $200 \mathrm{~km}^{2}$ [8].

In the Jiajika deposit, a total of more than 500 pegmatite dikes are distributed in an area of about $60 \mathrm{~km}^{2}$. Based on the mineral paragenetic associations, each pegmatite dike can be divided into 3 to 5 mineral zones. These zones are based on a typomorphic mineral, such that the pegmatite dikes can be divided into five types: (I) microcline pegmatite, (II) microcline-albite pegmatite, (III) albite pegmatite, (IV) spodumene pegmatite, and (V) lepidolite (muscovite) pegmatite. The dikes radiate around the granite intrusion both horizontally and vertically from the inner to outer in sequence (Figure 1). The dominant minerals of the Jiajika ore field pegmatites are microcline, albite, quartz, and muscovite. They coexist with rare-metal element-bearing minerals, such as spodumene, tantalite, beryl, thorite, and sicklerite $((\mathrm{Li}$, $\mathrm{Mn})\left(\mathrm{PO}_{4}\right)$ ), amongst others, and volatile-bearing minerals, such as tourmaline and fluorite [8].

In the Jiajika ore field, number 134 dike, located $1.8 \mathrm{~km}$ away from Jiajika granite intrusion (Figure 1), is the largest pegmatite dike with an estimated $\mathrm{Li}_{2} \mathrm{O}$ reserve of about 500,000 tons (with a grade of $1.2 \% \mathrm{Li}_{2} \mathrm{O}$ ) in an area of about $1055 \mathrm{~m}$ long and 20 100 m wide. Number 134 dike is hosted by an altered andalusite-staurolite mica schist, which was cordieritized, sericitized, and chloritized. The alteration zones are distributed in a circular shape around the pegmatite

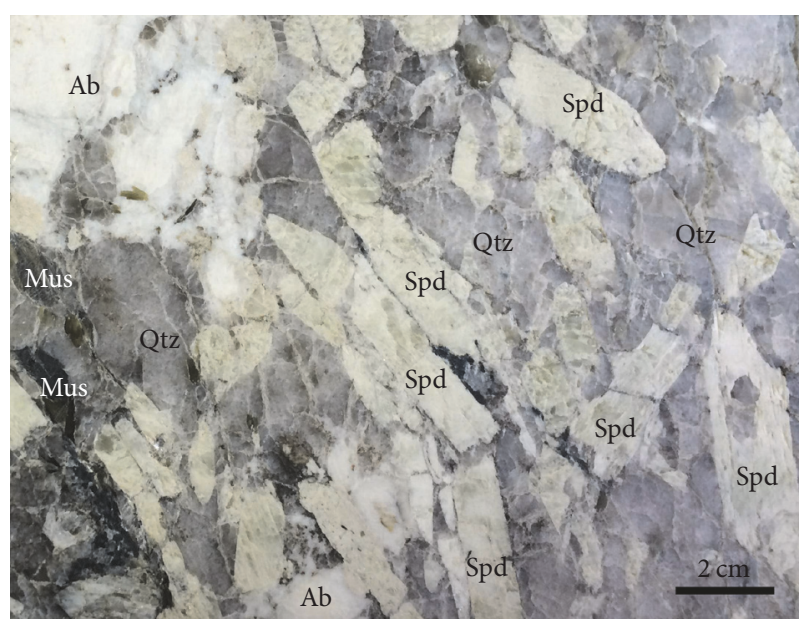

FIGURE 3: The sample photo of spodumene belt in number 134 dike in the Jiajika deposit, showing the coexistences of spodumene, quartz, albite, and muscovite. Spd: spodumene, Al: albite, Qtz: quartz, and Mus: muscovite.

dike. This dike can be divided into an inner spodumene zone and an outer albite zone (Figure 2). The spodumene belt occupies about 90 volume\% of the dike and is mainly composed of spodumene, quartz, albite, and muscovite; no petalite or its remnants were observed. The spodumene crystals are euhedral plates with white or off-white color, $(10-100) \times(5-10) \mathrm{mm}$ in size, and they have clear contacts with quartz and albite crystals. Quartz grows in the space among spodumene crystals (Figure 3 ).

\section{Fluid Inclusions in Number 134 Pegmatite Dike}

There are three types of inclusions in spodumene in spodumene belt from number 134 pegmatite dike: CIs, $\mathrm{CO}_{2}$ $\mathrm{H}_{2} \mathrm{O}-\mathrm{NaCl}$ inclusions, and aqueous inclusions. Most $\mathrm{CO}_{2}^{-}$ $\mathrm{H}_{2} \mathrm{O}-\mathrm{NaCl}$ and aqueous fluid inclusions are normally in round shape with sizes of less than $5 \mu \mathrm{m}$ and usually distributed along healed fractures that cross cut the spodumene laths and fluid inclusion assemblages (FIAs) of the CIs, indicating late entrapment and a secondary origin (Figures 4(a), 4(c), 4(d), and 4(f)). As shown in Figures 4(a) and 4(b), the late fluid trapped as $\mathrm{CO}_{2}-\mathrm{H}_{2} \mathrm{O}-\mathrm{NaCl}$ and aqueous inclusions reacted with the CIs, which became irregular in shape and do not provide any information on the primary trapped fluid. Usually, the more the late $\mathrm{CO}_{2}-\mathrm{H}_{2} \mathrm{O}-\mathrm{NaCl}$ and aqueous fluid inclusions were trapped in the spodumene crystal, the poorer the crystals transparency became. In these cases, only a few individual CIs survived without reaction with the late fluid and can be considered as primary. The CIs with primary features occur as isolated individuals or in FIAs, around which no reaction features with late fluid are observed, as shown in Figures 4(b), 4(c), 4(d), 4(e), and 4(f). The common sizes of the primary CIs are $(20-100) \times(10-20) \mu \mathrm{m}$ with a subhedral to euhedral negative spodumene crystal-shape (Figure 5). These CIs contain crystals, aqueous fluid, and a $\mathrm{CO}_{2}$ phase. 
TABLE 1: Results of homogenization experiments of CIs in spodumene from Jiajika deposit under external pressures in HDAC.

\begin{tabular}{|c|c|c|c|c|c|c|c|c|}
\hline Number $^{\mathrm{a}}$ & Number of FIA or ICI ${ }^{\mathrm{b}}$ & $S_{p}(\%)^{\mathrm{c}}$ & $T_{\mathrm{hDC}}\left({ }^{\circ} \mathrm{C}\right)^{\mathrm{d}}$ & $T_{\mathrm{hF}}\left({ }^{\circ} \mathrm{C}\right)^{\mathrm{e}}$ & $\mathrm{St}_{\mathrm{F}}{ }^{\mathrm{f}}$ & $T_{\mathrm{ID}}\left({ }^{\circ} \mathrm{C}\right)^{\mathrm{g}}$ & $T_{\mathrm{TD}}\left({ }^{\circ} \mathrm{C}\right)^{\mathrm{h}}$ & $P_{\mathrm{TD}}(\mathrm{MPa})^{\mathrm{i}}$ \\
\hline 1 & \multirow{2}{*}{1} & 25 & 295.7 & 290 & $\mathrm{~L}_{\mathrm{CO} 2}{ }^{\mathrm{k}}$ & 430 & 660 & 404 \\
\hline 2 & & 25 & 295.7 & 290 & $\mathrm{~L}_{\mathrm{CO} 2}$ & 451 & 650 & 393 \\
\hline 3 & \multirow{2}{*}{2} & 20 & 275.8 & 276 & $\mathrm{CT}^{1}$ & 415 & 622 & 425 \\
\hline 4 & & 20 & 275.8 & 292 & $\mathrm{CT}$ & 415 & 640 & 446 \\
\hline 5 & \multirow{3}{*}{3} & 5 & 268.8 & 278 & $\mathrm{~L}_{\mathrm{CO} 2}$ & 428 & 530 & 334 \\
\hline 6 & & 5 & 268.8 & 276 & CT & $-^{\mathrm{m}}$ & 535 & 340 \\
\hline 7 & & 5 & 268.8 & 289 & CT & 415 & 542 & 349 \\
\hline 8 & \multirow{2}{*}{4} & 5 & 268.7 & 272 & $\mathrm{CT}$ & 421 & 533 & 338 \\
\hline 9 & & 5 & 268.7 & 283 & $\mathrm{~L}_{\mathrm{CO} 2}$ & 400 & 525 & 328 \\
\hline 10 & \multirow{2}{*}{5} & 40 & 268.7 & 273 & $\mathrm{CT}$ & 418 & 650 & 480 \\
\hline 11 & & 40 & 268.7 & 274 & CT & 408 & 657 & 489 \\
\hline 12 & 6 & 40 & 268.8 & 282 & $\mathrm{~L}_{\mathrm{CO} 2}$ & 419 & 705 & 545 \\
\hline 13 & 7 & 25 & 278.0 & 300 & $\mathrm{~L}_{\mathrm{H} 2 \mathrm{O}}{ }^{j}$ & 421 & 620 & 415 \\
\hline 14 & 8 & 30 & 278.0 & 304 & $\mathrm{~L}_{\mathrm{H} 2 \mathrm{O}}$ & 430 & 660 & 461 \\
\hline 15 & 9 & 30 & 275.8 & 298 & $\mathrm{CT}$ & 415 & 680 & 492 \\
\hline 16 & 10 & 30 & 271.5 & 280 & $\mathrm{CT}$ & 430 & 650 & 471 \\
\hline 17 & 11 & 5 & 276.1 & 360 & CT & 424 & 510 & 290 \\
\hline 18 & 12 & 5 & 270.6 & 267 & CT & - & 530 & 315 \\
\hline 19 & 13 & 10 & 276.1 & 281 & CT & 424 & 650 & 456 \\
\hline 20 & 14 & 40 & 261.1 & 286 & CT & 408 & 646 & 501 \\
\hline 21 & 15 & 5 & 295.7 & 277 & CT & 460 & 592 & 331 \\
\hline 22 & 16 & 35 & 269.8 & 283 & $\mathrm{~L}_{\mathrm{CO} 2}$ & 460 & 601 & 418 \\
\hline 23 & 17 & 15 & 224.5 & 287 & $\mathrm{~L}_{\mathrm{H} 2 \mathrm{O}}$ & 442 & 608 & 571 \\
\hline 24 & 18 & 5 & 272.1 & 287 & CT & 480 & 560 & 362 \\
\hline 25 & 20 & 10 & 264.0 & 287 & CT & 480 & 560 & 385 \\
\hline 26 & 21 & 10 & 266.4 & 292 & $\mathrm{~L}_{\mathrm{CO} 2}$ & 470 & 608 & 437 \\
\hline 27 & 22 & 30 & 294.0 & 294 & $\mathrm{~L}_{\mathrm{CO} 2}$ & 390 & 720 & 472 \\
\hline 28 & 23 & 15 & 294.0 & 280 & $\mathrm{~L}_{\mathrm{H} 2 \mathrm{O}}$ & - & 530 & 269 \\
\hline 29 & 24 & 15 & 295.4 & 288 & $\mathrm{~L}_{\mathrm{CO} 2}$ & - & 560 & 298 \\
\hline 30 & 25 & 25 & 231.3 & 295 & $\mathrm{~L}_{\mathrm{CO} 2}$ & - & 572 & 499 \\
\hline 31 & 26 & 30 & 250.0 & - & $\mathrm{L}_{\mathrm{CO} 2}$ & 420 & 635 & 524 \\
\hline 32 & 27 & 10 & 250.0 & - & $\mathrm{L}_{\mathrm{CO} 2}$ & 430 & 500 & 345 \\
\hline 33 & 28 & 50 & 275.1 & 291 & $\mathrm{~L}_{\mathrm{CO} 2}$ & 415 & 600 & 401 \\
\hline
\end{tabular}

${ }^{\mathrm{a}}$ Number of CIs; ${ }^{\mathrm{b}}$ number of fluid inclusion assemblages of CIs or isolated CIs; ${ }^{\mathrm{c}} S_{\mathrm{p}}$ : volume proportion of solid phases in CIs at room temperature; ${ }^{\mathrm{d}} T_{\mathrm{hDC}}$ : disappearance temperature of $\mathrm{H}_{2} \mathrm{O}$ vapor bubble in $\mathrm{HDAC}$ cell; ${ }^{\mathrm{e}} \mathrm{T}_{\mathrm{hF}}$ : homogenization temperature of fluid phase in CIs; ${ }^{\mathrm{f}} \mathrm{St}_{\mathrm{F}}$ : state of the homogenized fluid in CIs; ${ }^{g} T_{\mathrm{ID}}$ : initial dissolution temperature of daughter minerals in CIs; ${ }^{\mathrm{h}} \mathrm{T}_{\mathrm{TD}}$ : total dissolution temperature of daughter minerals in CIs; ${ }^{\mathrm{i}} \mathrm{P}_{\mathrm{TD}}$ : pressure in $\mathrm{HDAC}$ at the $T_{\mathrm{TD}}$ (i.e., external pressure of CIs at $T_{\mathrm{TD}}$ ); calculated from densities obtained from $T_{\mathrm{hDC}}$ using the equation of state of $\mathrm{H}_{2} \mathrm{O}$ formulated by Zhang and Duan [27], which is more accurate than that by Haar et al. [28] based on recent calibrations using $\alpha-\beta$ quartz phase transition [29]; ${ }^{j} \mathrm{~L}_{\mathrm{H} 2 \mathrm{O}}$ : liquid $\mathrm{H}_{2} \mathrm{O}$; ${ }^{\mathrm{k}} \mathrm{L}_{\mathrm{CO} 2}$ : liquid $\mathrm{CO}_{2} ;{ }^{1} \mathrm{CT}$ : critical phase of $\mathrm{H}_{2} \mathrm{O}$ and $\mathrm{CO}_{2} ;{ }^{\mathrm{m}} \mathrm{T}_{\mathrm{ID}}$ or $T_{\mathrm{hF}}$ was not obvious or not observed during heating.

CIs with primary features are characterized by euhedral crystals commonly surrounded by an aqueous fluid (Figures 5(a), 5(b), and 5(e)), while the semieuhedral crystals are attached to the wall of the CI chamber or at the extreme ends of the CI chamber (Figure 5). Raman spectroscopy showed that these CIs commonly contain cristobalite, which always coexists with zabuyelite $\left(\mathrm{Li}_{2} \mathrm{CO}_{3}\right)$ and occasionally with other minerals, including calcite, spodumene, lithiophosphate, and possibly cookeite [30] (Figure 5). The estimated volume proportion of the total solid phases in the most of the CIs is about 5 to $\sim 60 \%$ (Figure 5, Table 1). The $\mathrm{CO}_{2}$ phase occupies about $10 \sim 80$ volume $\%$ of the fluid phase (Figure 5 ). Although not all CIs with primary features exhibit the same crystal/fluid ratio and $\mathrm{CO}_{2}$ volume\%, this type of $\mathrm{CI}$ in one FIA usually have a similar crystal/fluid proportion and $\mathrm{CO}_{2}$ volume\% as shown in Figure 4(f).

We also observed a few $\mathrm{CO}_{2}$-rich aqueous fluid inclusions with a similar shape and size as CIs at room temperature, which coexist with the CIs. They could be formed through necking of CIs as suggested by London [3] and Anderson et al. [21]. They also could be fluid inclusions that resulted from the crystallization of spodumene and/or other daughter 


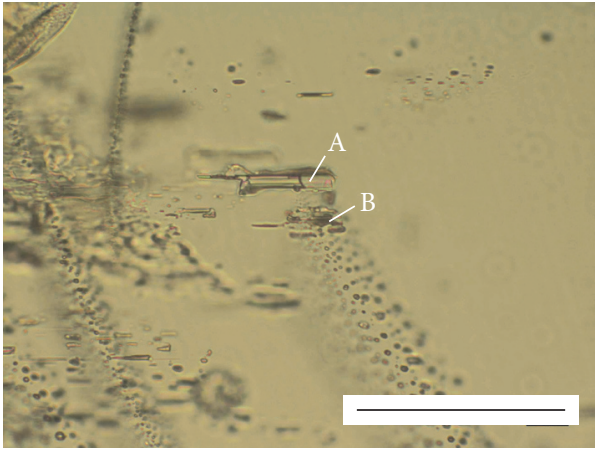

(a)

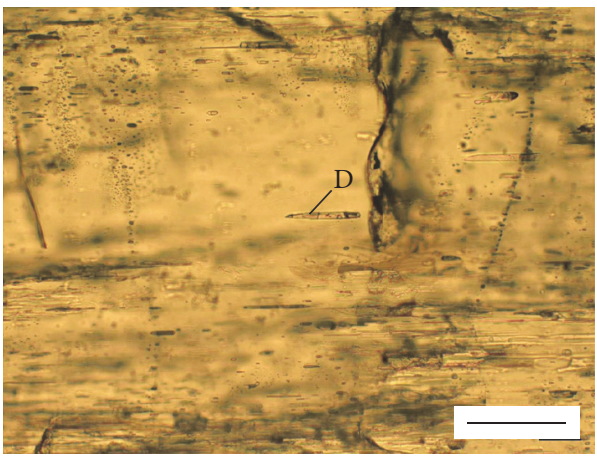

(c)

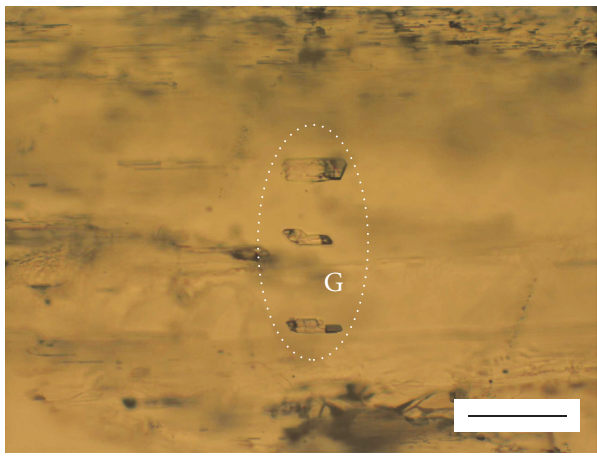

(e)

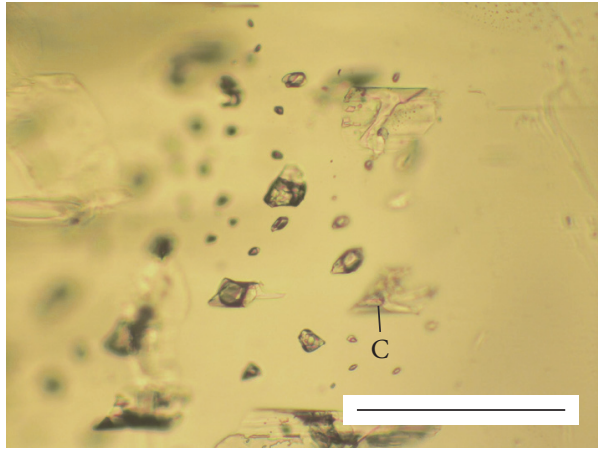

(b)

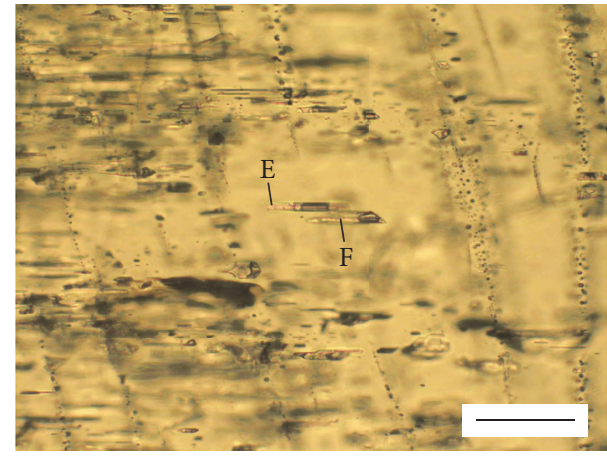

(d)

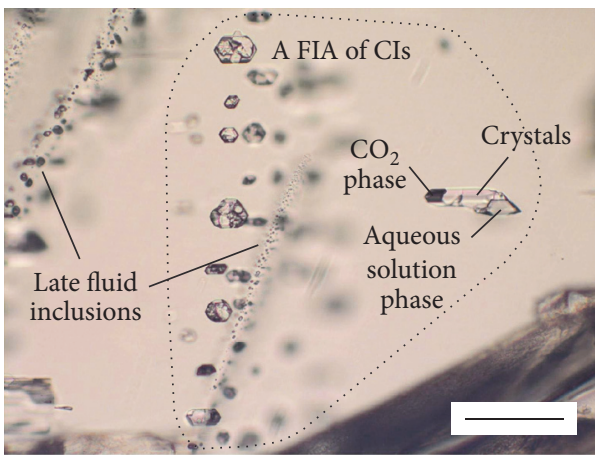

(f)

FIgURE 4: The fluid inclusions and crystal-rich inclusions hosted in spodumene. (a) shows the alterations of crystal-rich inclusions (CIs) "A" and "B" by the late aqueous fluid. In (b), except CI "C" that was destroyed by late fluid, other CIs occurred in one fluid inclusion assemblage (FIA) showing similar crystal/fluid proportion and $\mathrm{CO}_{2}$ volume\%. In (c), an isolated CI "D" showed primary features without alteration by late fluid. In (d), the CIs "E" and "F" belong to a FIA with similar crystal/fluid proportions and $\mathrm{CO}_{2}$ volume\% and without alteration by late fluid, which occurred along the nearby healed fractures. (e) shows that three CIs belong to a FIA "G." (f) shows a FIA of CIs with similar crystal/fluid proportion that was cut by small aqueous fluid inclusions distributing along healed fractures. The CIs have a negative spodumene crystal-shape. The length of the scale bar in black is $100 \mu \mathrm{m}$.

minerals on the wall of the CIs from the entrapped liquid during cooling, such that they had no obvious daughter minerals. This origin is supported by the observation that the total homogenization temperatures (about $290^{\circ} \mathrm{C}$ ) of many of these daughter mineral-free $\mathrm{CO}_{2}$-rich fluid inclusions are close to the homogenization temperatures of the fluid phases within the CIs [8].

Many isolated $\mathrm{CO}_{2}$-rich fluid inclusions and a few crystalbearing inclusions, which are circular or elliptical in shape with sizes of 10 to $\sim 50 \mu \mathrm{m}$ and homogenization temperatures of between 220 and $565^{\circ} \mathrm{C}$ ( $\mathrm{Li}$ and $\mathrm{Li}, 2015$ ), were found in quartz that grew among spodumene crystals.

\section{Experimental Method}

A hydrothermal diamond-anvil cell (HDAC; type V; Anderson et al. [24]; Li et al. [25]) was used in our homogenization experiments of CIs (Figure 6). The CIs were hosted in seven spodumene crystals collected from different localities in the inner spodumene belt of number 134 pegmatite dike. 


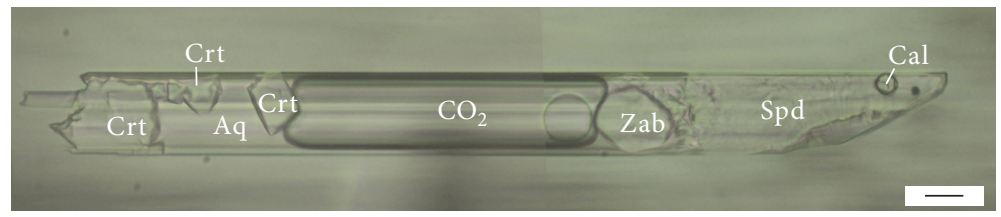

(a)

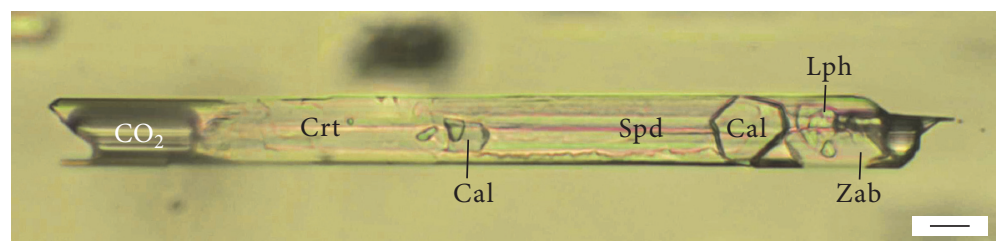

(b)

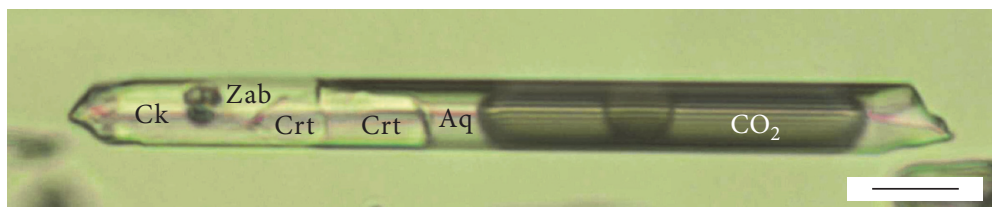

(c)

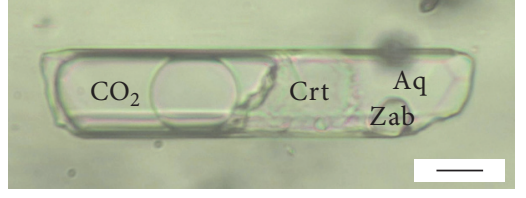

(d)

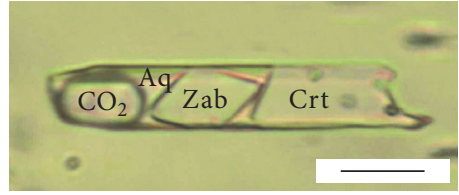

(e)

FIGURE 5: The crystal-rich inclusions hosted in spodumene from the Jiajika deposit. Crt- critobalite, Spd- spodumene, Zab-Zabuyelite, Calcalcite, Qz- quartz, Ck- cookeite, Aq- aqueous fluid, $\mathrm{CO}_{2}-\mathrm{CO}_{2}$ fluid. The length of the scale bar in black is $10 \mu \mathrm{m}$.

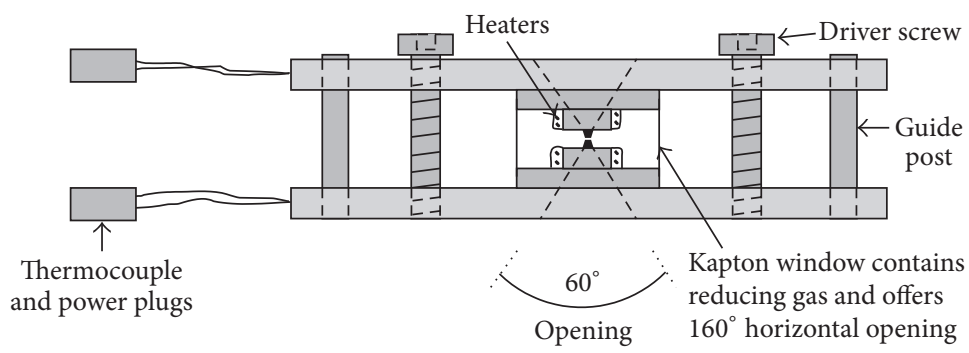

FIGURE 6: A schematic drawing of the type V hydrothermal diamond-anvil cell [24, 25].

This type of HDAC permits the use of a 50x objective lens for observing samples in situ for a long period of time at relatively high temperatures (near $850^{\circ} \mathrm{C}$ ). As a result, we were able to extend the method and procedures, which are described by Schmidt et al. [31] and Darling and Bassett [32], for homogenization experiments in an HDAC to much higher temperatures for melt inclusions. A spodumene wafer containing CIs together with water was placed in a sample chamber consisting of a hole ( $1.0 \mathrm{~mm}$ dia.) at the center of a $\mathrm{Re}$ gasket ( $3.0 \mathrm{~mm}$ dia. and $0.25 \mathrm{~mm}$ thick) placed between the two diamond-anvil faces ( $1.6 \mathrm{~mm}$ dia.). The sample was sealed with a vapor bubble of suitable size in the chamber by compressing and deforming the Re gasket with the two diamondanvil faces (Figure 7), such that the sample was surrounded by a water pressure medium with a suitable bulk $\mathrm{H}_{2} \mathrm{O}$ density in the chamber. Because the spodumene crystals in the Jiajika deposit host so many CIs, it was not necessary to use the laser cutting method to prepare the sample as described by Darling and Bassett [32]. Samples of adequate size were prepared by breaking the doubly polished spodumene slides $(<200 \mu \mathrm{m}$ in thickness) into small pieces $(<1 \mathrm{~mm}$ in both dimensions), then selecting individual CI-bearing pieces for our homogenization experiments. Sample temperatures in the HDAC were measured with two type-K thermocouples with their temperature sensing tips attached separately to the two diamonds. The thermocouples were calibrated by the triple point of $\mathrm{H}_{2} \mathrm{O}\left(0.01^{\circ} \mathrm{C}\right)$ and the melting points of $\mathrm{NaNO}_{3}$ $\left(306.8^{\circ} \mathrm{C}\right)$ and $\mathrm{NaCl}\left(800.5^{\circ} \mathrm{C}\right)$; the reported temperatures 


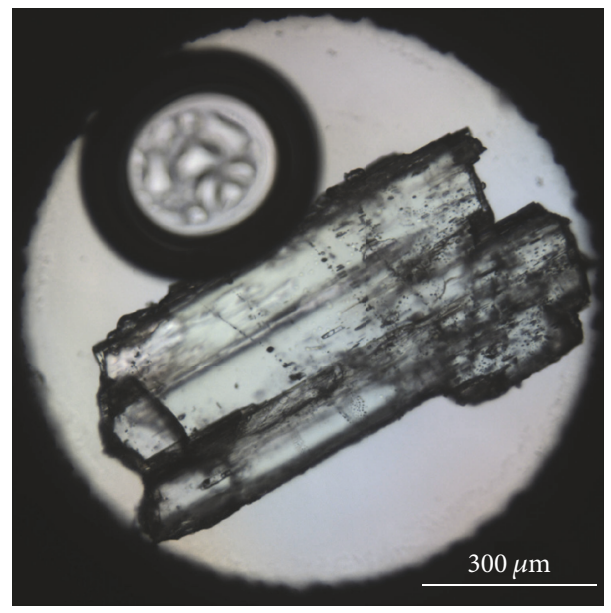

FIGURE 7: A photo showing a vapor bubble and a spodumene wafer in the sample chamber of HDAC.

were accurate to $\pm 3^{\circ} \mathrm{C}$. A Linkam temperature controller (Linkam TMS 94) was used to control sample temperatures, and a video system was used to record sample images through a Mitutoyo 50x long-working-distance objective lens.

As described by Bassett et al. [33], the sample pressure in the HDAC can be calculated using the equation of state for $\mathrm{H}_{2} \mathrm{O}$ [27], at any temperature from the bulk $\mathrm{H}_{2} \mathrm{O}$ density in the sample chamber. Assuming pure $\mathrm{H}_{2} \mathrm{O}$ is the pressure medium, the bulk $\mathrm{H}_{2} \mathrm{O}$ density is determined by the homogenization temperature of the liquid and vapor phases (i.e., the temperature of disappearance of the vapor bubble). Because the fluid phases of $\mathrm{H}_{2} \mathrm{O}-\mathrm{CO}_{2}-\mathrm{NaCl}$ in CIs homogenized (to liquid) at about $290^{\circ} \mathrm{C}$ [8], the homogenization temperature of the $\mathrm{H}_{2} \mathrm{O}$ vapor bubble inside the HDAC chamber was adjusted to be near $290^{\circ} \mathrm{C}$ by sealing $\mathrm{H}_{2} \mathrm{O}$ with a vapor bubble of about 75 volume $\%$ of the sample chamber. This allowed a fast increase in the CI internal pressure, after homogenization of the fluid phases during heating. This was roughly balanced by the external pressures on the CI generated within the HDAC sample chamber such that stretching was minimized and the decrepitation of the CIs was prevented. This also prevented leakage of volatiles from CIs. During heating, the initial heating rate of $30^{\circ} \mathrm{C} / \mathrm{min}$ was decreased to $1^{\circ} \mathrm{C} / \mathrm{min}$ and then kept at this rate as the temperature approached the initial melting temperature of the daughter minerals. This allowed the melting to be kept at an almost equilibrium condition such that the measured temperatures were close to the actual temperatures at this slow rate of heating [34]. Also, the duration time of heating in our homogenization experiments was normally kept at less than $6 \mathrm{~h}$, so that the possibility of fluid leakage from CIs was minimized greatly when compared with those in the experiments using coldsealed pressure vessels with long heating durations [35].

\section{Results}

In our homogenization experiments, we selected 33 CIs with primary features that occurred either as isolated CI or in FIAs. Experimental results are listed in Table 1.
During heating, the temperature at which the $\mathrm{H}_{2} \mathrm{O}$ vapor bubble disappeared in the HDAC $\left(T_{\mathrm{hDC}}\right)$; the homogenization temperature $\left(T_{\mathrm{hF}} ; \sim 290^{\circ} \mathrm{C}\right)$ and the homogenization state $\left(\mathrm{St}_{\mathrm{F}}\right)$ of the fluid phase in the CIs; the initial dissolving temperature of crystals $\left(T_{\mathrm{ID}} ; 400\right.$ to $\left.\sim 500^{\circ} \mathrm{C}\right)$; and the temperature at which all crystals in $\mathrm{CO}_{2}$-aqueous fluid within the $\mathrm{CI}$ dissolved totally $\left(T_{\mathrm{TD}} ; 500\right.$ to $\left.\sim 720^{\circ} \mathrm{C}\right)$ were recorded (Table 1). During heating, the first observed phase transition in the CIs was the homogenization of the $\mathrm{CO}_{2}$ + an aqueous phase into a supercritical fluid with nearcritical homogenization (Table 1). Cristobalite was usually the first phase dissolved in the supercritical fluid, followed by zabuyelite $\left(\mathrm{Li}_{2} \mathrm{CO}_{3}\right)$ and the silicate minerals until their total dissolution at $T_{\mathrm{TD}}$ (Figure 8). As shown in Table 1, all the CIs have similar $T_{\mathrm{ID}}$, and the CIs in the FIAs, with a similar volume proportion of solid phases, usually have a similar $T_{\mathrm{TD}}$. As shown in Figure 9, $T_{\mathrm{TD}}$ tends to increase as the volume proportion of solid phases in the CIs increases.

When compared with the original samples, we noticed the following changes in CIs after total homogenization at $T_{\mathrm{TD}}$ : (1) a small decrease in $T_{\mathrm{hF}}$ 's of the $\mathrm{H}_{2} \mathrm{O}-\mathrm{CO}_{2}-\mathrm{NaCl}$ fluid phase when remeasured; (2) no glass or daughter minerals were observed in CIs during or after cooling (Figure 10); (3) the sizes of CIs became smaller, especially those with high $T_{\mathrm{TD}}$ under the corresponding high external pressure (e.g., Figures 10(D-1) and 10(D-2)).

The pressures in HDAC at $T_{\mathrm{TD}}$ were calculated from the bulk $\mathrm{H}_{2} \mathrm{O}$ densities obtained from $T_{\mathrm{hDC}}$ using the equation of state of $\mathrm{H}_{2} \mathrm{O}$ [27]. Results are listed in Table 1 and shown in Figure 11. These pressures are external pressures on the spodumene of the CIs at $T_{\mathrm{TD}}$. As shown in Figure 11, they are within or near the stability field for spodumene in the system $\mathrm{LiAlSiO}_{4}-\mathrm{SiO}_{2}-\mathrm{H}_{2} \mathrm{O}$.

\section{Discussion}

In our experiments, the selected CIs with primary features occurred either as isolated inclusions with the subhedral to euhedral negative crystal-shape of spodumene or in a FIA, in 

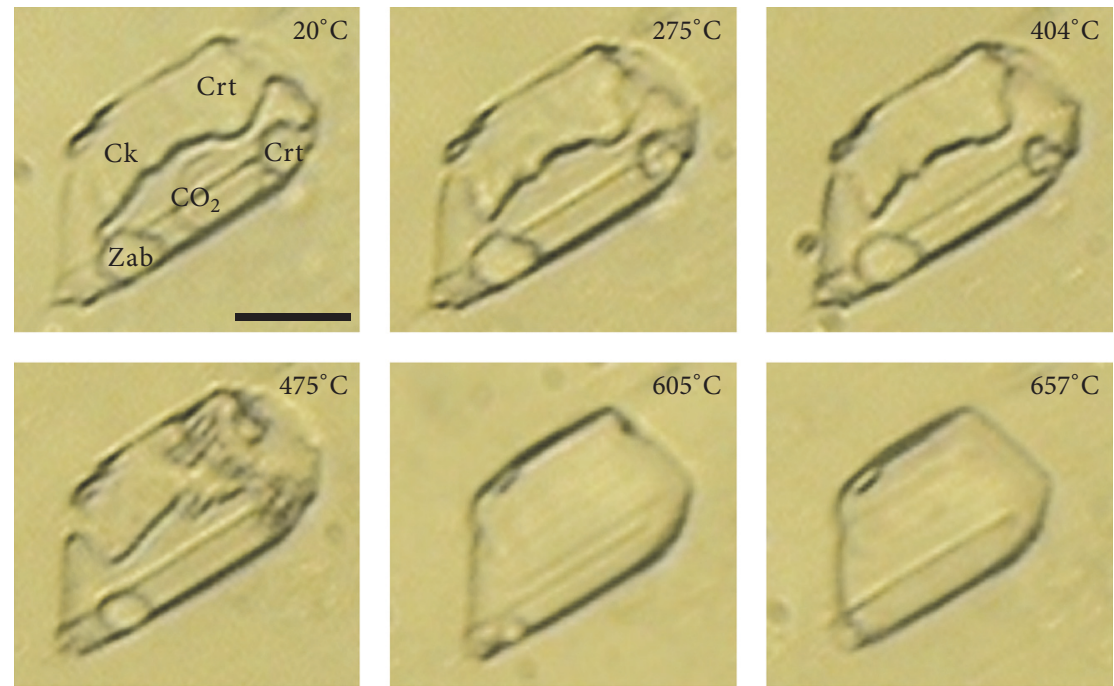

(a)
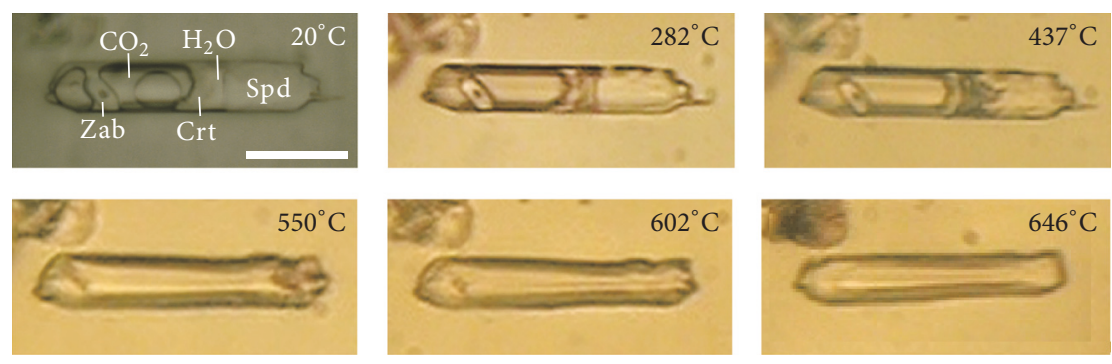

(b)
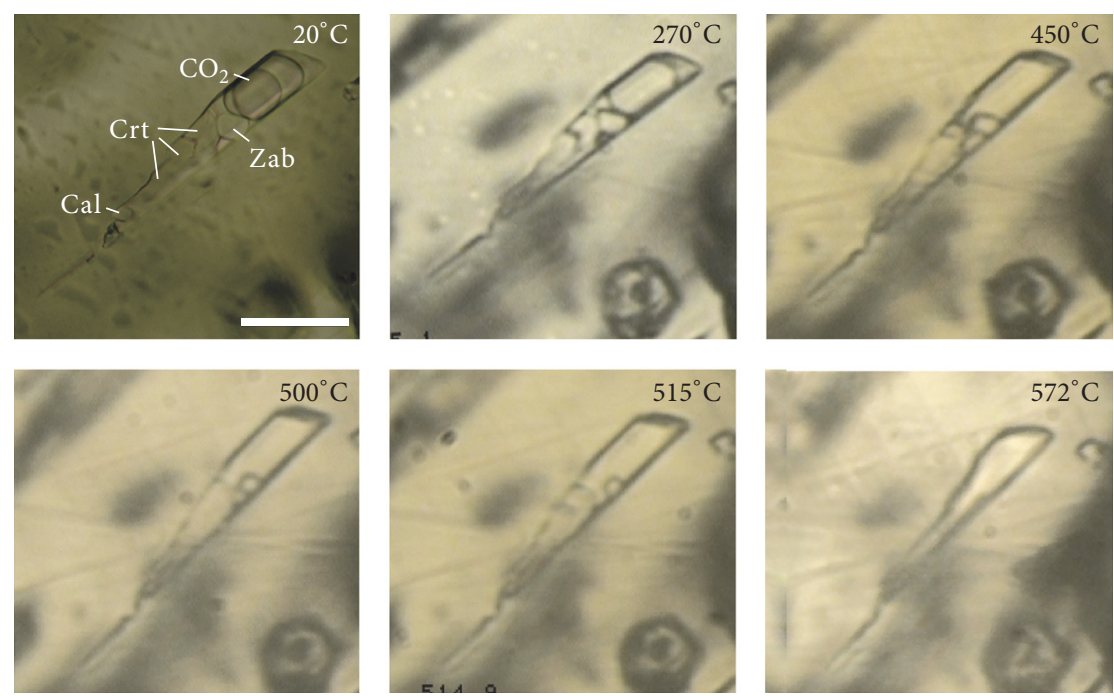

(c)

FIGURE 8: The homogenization processes of CIs in spodumene from the Jiajika deposit, China. Recorded images of (a), (b), and (c) are from experimental numbers 3,12 and 30 respectively. They show the dissolution of melt into the carbonic aqueous fluid during the total homogenization process. Zab-Zabuyelite, Crt- Cristobalite, Cal- Calcite, Ck- cookeit. The length of the scale bar is $10 \mu \mathrm{m}$.

which the fluid inclusions normally have similar crystal/fluid proportions and a $\mathrm{CO}_{2}$ volume\% (Figure 4). These CIs did not suffer from secondary alteration reactions with late fluids nor had obvious necking features with no observed coexistence of $\mathrm{CIs}$ and $\mathrm{H}_{2} \mathrm{O}-\mathrm{CO}_{2}-\mathrm{NaCl}$ fluid inclusions. Besides these features, the following evidences indicate that the CIs with primary features in the Jiajika deposit remain closed after their entrapments. (1) Perfect crystals in the CIs were commonly surrounded by an aqueous fluid (Figure 5(a)), which was produced through the enrichment of $\mathrm{H}_{2} \mathrm{O}$ in 


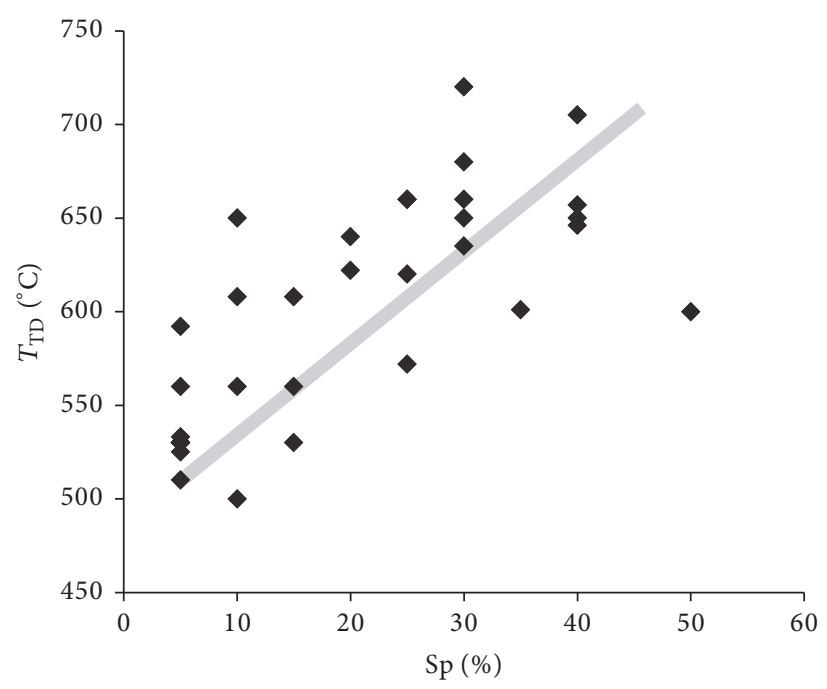

FIGURE 9: The diagram showing the relationship between the volume proportion of solid phases (Sp) and the total dissolution temperature of crystals within CIs $\left(T_{\mathrm{TD}}\right)$. The grey line shows the trend that $T_{\mathrm{TD}}$ tends to increase as the volume proportion of the solid phases in the CIs increases.

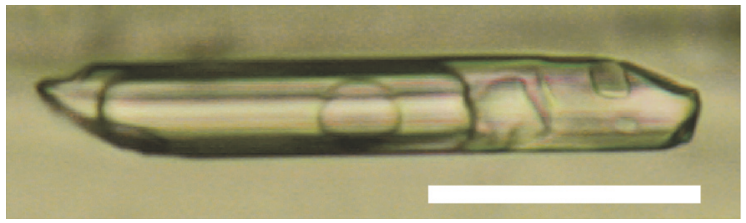

(A-1)

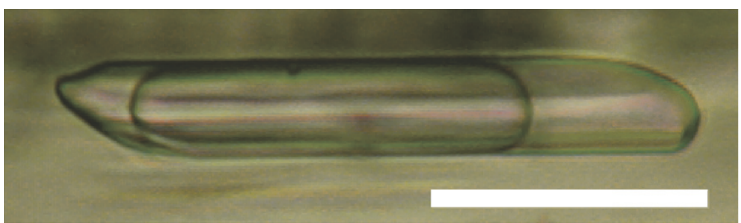

$(\mathrm{A}-2)$

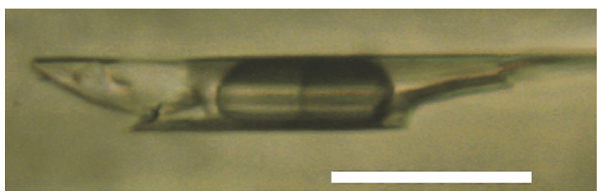

(C-1)

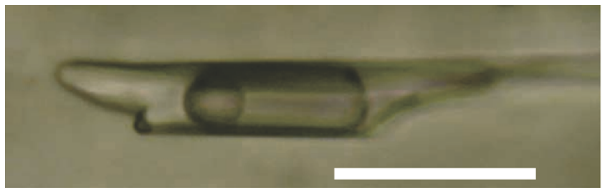

(C-2)

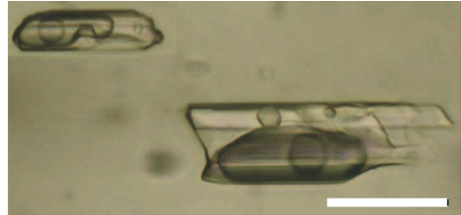

(B-1)

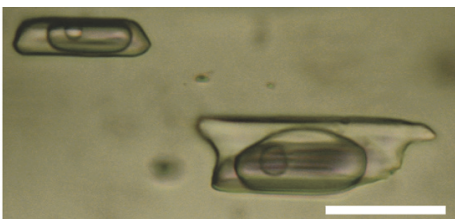

(B-2)

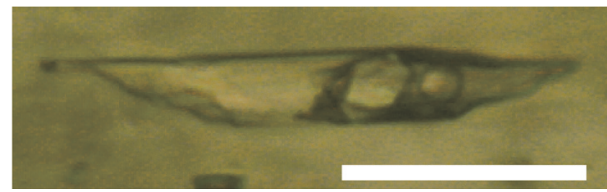

(D-1)

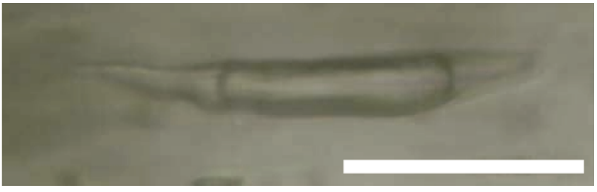

(D-2)

Figure 10: Photomicrographs of CIs in spodumene from the Jiajika deposit at room temperature before heating (A-1, B-1, C-1, and D-1) and after the homogenization experiments (A-2, B-2, C-2, and D-2). Note that, after the homogenization experiments, the original daughter minerals failed to nucleate and the corners of the CIs became rounded with slight decreases in the volumes of the inclusions. The length of the scale bar is $10 \mu \mathrm{m}$.

the remaining liquid during crystallization within the CIs and enhanced crystallization [25,36]. (2) The occurrence of cristobalite in the CIs indicates that the CIs were entrapped at relatively high temperatures, because cristobalite is stable at high temperatures $[37,38]$ and was formed due to a pressure decrease within the CIs, mainly resulting from crystallization of the zabuyelite [30]. (3) Cristobalite only occurred within the CIs, while the host spodumene grew together with quartz, indicating that the cristobalite was not an accidentally trapped mineral during the formation of the 


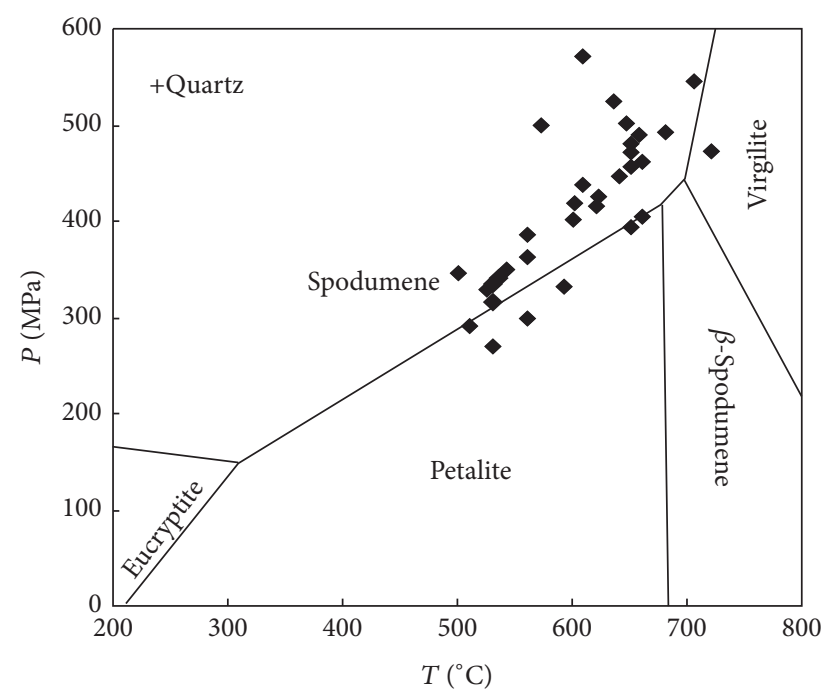

FIgURe 11: $P$-T conditions in the HDAC during the total homogenization temperatures of CIs $\left(T_{\mathrm{TD}}\right)$. Note that these are not the $P$ $T$ conditions in the CIs (for details, see text). The phase diagram is from London [26] for the system $\mathrm{LiAlSiO}_{4}-\mathrm{SiO}_{2}-\mathrm{H}_{2} \mathrm{O}$. The plotted pressures are the $P_{\mathrm{TD}}$ values listed in Table 1.

CIs. Otherwise, quartz, rather than cristobalite, should be commonly observed in the CIs. (4) CIs in a FIA normally have a similar composition and $T_{\mathrm{ID}}$ and $T_{\mathrm{TD}}$ values, as shown in Table 1, indicating that the CIs were entrapped in the same geological environment without alteration by late fluids. These features indicate that CIs with primary features in spodumene in the Jiajiaka deposit are primary in origin and that the study of homogenization processes of these primary CIs will bear directly on the origin of the host pegmatite.

In our HDAC experiments, most of the external pressures on the samples at $T_{\mathrm{TD}}$ were within the stability field of spodumene + quartz, as shown in the P-T phase diagram of the system $\mathrm{LiAlSiO}_{4}-\mathrm{SiO}_{2}-\mathrm{H}_{2} \mathrm{O}$ (Figure 11). There is no a priori reason for these external pressures to be the same as the internal pressures of the CIs. However, based on the phase diagram shown in Figure 11, the external pressures listed in Table 1 are considered to be near the minimum formation pressure of the host spodumene, because of the absence of virgilite $\left(\mathrm{LiAlSi}_{2} \mathrm{O}_{6}\right), \beta$-spodumene, and petalite $\left(\mathrm{LiAlSi}_{4} \mathrm{O}_{10}\right)$ at the Jiajika deposit. Here, it was assumed that the strength of the spodumene crystal lattice to sustain the pressure difference between the inside and outside of the CI at $T_{\mathrm{TD}}$ is limited. The size of a few CIs became smaller while crystals were dissolving in the aqueous fluid during heating (Figures 8(a), 10(D-1), and 10(D-2)), which indicates that the applied external pressure may be higher than the pressure within the CIs. This kind of volume reduction in the fluid inclusions was also inferred previously in homogenization experiments of fluid inclusions in the HDAC, where the total homogenization temperature decreased with an increase in the external pressure on the fluid inclusion ([31]; Darling et al., 2002; Li et al., 2015).

Results from our homogenization experiments of CIs in spodumene in the HDAC indicate that, during heating, crystals within CIs dissolved in the carbonic aqueous fluid. Mustart [39], Thomas and Davidson [40], and Thomas et al. $[11,20]$ showed that, during heating, $\mathrm{SiO}_{2}$ can be dissolved in alkali- and carbonate-rich aqueous fluid as alkali disilicates. Therefore, zabuyelite and cristobalite, the main daughter minerals in CIs, could dissolve into a carbonic aqueous fluid via the following reactions:

$$
\begin{aligned}
& \mathrm{Li}_{2} \mathrm{CO}_{3}+2 \mathrm{SiO}_{2}+\mathrm{CO}_{2}+\mathrm{H}_{2} \mathrm{O} \longrightarrow 2 \mathrm{LiHCO}_{3}+2 \mathrm{SiO}_{2} \\
& \longrightarrow \mathrm{Li}_{2} \mathrm{Si}_{2} \mathrm{O}_{5}+2 \mathrm{CO}_{2}+\mathrm{H}_{2} \mathrm{O} \\
& \longrightarrow \text { Carbonate and aqueous-rich liquid }
\end{aligned}
$$

As shown in Figure 9, the more solid phases within a $\mathrm{CI}$, the higher the temperature for dissolving all crystals into the aqueous fluid in the CI. These phenomena are in agreement with the observation that the solubility of quartz in an $\mathrm{Na}_{2} \mathrm{CO}_{3}$ solution increases with $P$ and $T$ and is always much higher than its solubility in water under the same $P-T$ condition [41]. When cooled to room temperature after the total homogenization experiment, the dissolved components appear to be deposited on the wall of the original fluid inclusion, such that its volume is decreased. In addition, some $\mathrm{CO}_{2}$ may be released from the zabuyelite and subsequently lower $T_{\mathrm{hF}}$ 's of the $\mathrm{H}_{2} \mathrm{O}-\mathrm{CO}_{2}-\mathrm{NaCl}$ fluid phase when remeasured after the first homogenization measurement.

$T_{\mathrm{TD}}$ 's listed in Table 1 are consistent with the crystallization temperature of spodumene in an aqueous fluid, which are 775 to $\sim 530^{\circ} \mathrm{C}$ at pressures of 600 to $\sim 300 \mathrm{MPa}$ [25]. Also, these $T_{\mathrm{TD}}$ 's $\left(500-720^{\circ} \mathrm{C}\right)$ are in agreement with the inferred crystallization pressure of spodumene of about 300 to $\sim 500 \mathrm{MPa}$ for common and some rare-metal pegmatites [15] according to the phase diagram of $\mathrm{LiAlSiO}_{4}-\mathrm{SiO}_{2}-\mathrm{H}_{2} \mathrm{O}$ [26]. Therefore, the measured $T_{\mathrm{TD}}$ appears to be near the total homogenization temperature and thus could be considered as the minimum temperature for the entrapment of CIs.

The observed homogenization process in CIs indicates that a carbonate-rich aqueous fluid is able to transport the elements making up the minerals in the CI to the crystallization front in the pegmatite, as observed in the crystallization experiments of spodumene in the HDAC [25]. In addition, the compositions of the dissolved daughter minerals observed within the CIs indicate that this type of carbonate aqueous fluid is rich in silicate and alkali metals. Its composition appears to be close to that of hydrosilicate liquids with a low viscosity, high element diffusion, and a capacity for mass transport, enabling extreme concentrations of lithophile ore metals [42, 43]. These observations provide useful information for evaluating the formation models of the rare-metal pegmatites, such as those suggested by London [15], Thomas et al. [19], and Thomas and Davidson [40].

\section{Conclusions}

A total of 33 CI homogenization experiments in spodumene from the Jiajika deposit, China, were performed in an HDAC, allowing for the in situ observation of the total homogenization of the $\mathrm{CI}$ at temperatures and pressures approximating the formation conditions for spodumene. Our 
approach prevented the decrepitation of CIs and eliminated the shortcomings of other experimental methods, including decrepitation of CIs during homogenization experiments at one atm. external pressure and erroneous conclusions based on analyses of quenched samples in experiments performed in cold-seal pressure vessels. Therefore, the HDAC is an ideal apparatus for effectively performing homogenization experiments of CIs under pressure, especially for fluid or melt inclusions enriched in $\mathrm{H}_{2} \mathrm{O}, \mathrm{CO}_{2}$, and other volatiles that generate high internal pressure during heating.

In the homogenization experiments, the crystals within the CIs were dissolved in a carbonic-rich aqueous fluid during heating. The measured $T_{\mathrm{TD}}$ 's of the CIs were between 500 and $720^{\circ} \mathrm{C}$, and pressures in the HDAC cell at $T_{\mathrm{TD}}$ were mostly within the stability field of spodumene + quartz. These $T_{\mathrm{TD}}$ 's can be regarded as temperature range for the entrapment of CIs. This temperature range is in agreement with the crystallization temperatures of pegmatites derived from other observations or measurements. These results indicate that CIs represent an entrapped carbonate- and silica-rich aqueous fluid. Overall the homogenization experiments provide useful information for evaluating various formation models of rare-metal pegmatites.

\section{Conflicts of Interest}

The authors declare that they have no conflicts of interest.

\section{Acknowledgments}

The authors thank Professor W. A. Bassett for providing type V HDAC and helpful discussions. This study was supported by the National Key R\&D Program of China (2017YFC0602701), the National Natural Science Foundation of China (41372088), the Chinese National Nonprofit Institute Research Grant of CAGS-IMR (K1409), and the Knowledge Innovation Program (SIDSSE-201302), the Hadal-Trench Research Program (XDB06060100), and the Key Frontier Science Program (QYZDY-SSW-DQC008) of Chinese Academy of Sciences.

\section{References}

[1] E. Roedder, "Fluid inclusions," Mineralogical Society of America Reviews in Mineralogy, vol. 12, 1984.

[2] E. Roedder, "Fluid inclusion evidence for immiscibility in magmatic differentiation," Geochimica et Cosmochimica Acta, vol. 56, no. 1, pp. 5-20, 1992.

[3] D. London, "Magmatic-hydrothermal transition in the Tanco rare-element pegmatite: evidence from fluid inclusions and phase-equilibrium experiments," American Mineralogist, vol. 71, no. 3-4, pp. 376-395, 1986.

[4] D. London, "Formation of tourmaline-rich gem pockets in miarolitic pegmatites," American Mineralogist, vol. 71, no. 3-4, pp. 396-405, 1986.

[5] C. Wu, J. Zhu, C. Liu, S. Yang, B. Zhu, and G. Ning, "A study on the inclusions in spodumenes from Altai pegmatite (in Chinese with English abstract)," Xingjiang. Geotectonica et Metallogenia, vol. 18, pp. 353-362, 1995, in Chinese with English abstract.
[6] H. Lu, Z. Wang, and Y. Li, "Magma/fluid transition and genesis of pegamatite Dike No. 3 at Altay Xinjiang (in Chinese with English abstract)," Acta Mineralogica Sinia, vol. 61, pp. 1-7, 1996.

[7] J. Zhu, C. Wu, C. Liu, F. Li, X. Huang, and D. Zhou, "Magmatichydrothermal evolution and genesis of Koktokay No. 3 rare metal pegmatite dyke, Altai, China (in Chinese with English abstract)," Geological Journal of China Universities, vol. 6, pp. 40-52, 2000.

[8] J. Li, D. Wang, D. Zhang, and X. Fu, Mineralizing Mechanism and Continental Geodynamics of Typical Pegmatite Deposits in Western Sichuan, China (in Chinese with English abstract), Atomic Energy Press, Beijing, China, 2007.

[9] R. Thomas and J. D. Webster, "Strong tin enrichment in a pegmatite-forming melt," Mineralium Deposita, vol. 35, no. 6, pp. 570-582, 2000.

[10] R. Thomas, P. Davidson, and E. Badanina, "A melt and fluid inclusion assemblage in beryl from pegmatite in the Orlovka amazonite granite, East Transbaikalia, Russia: Implications for pegmatite-forming melt systems," Mineralogy and Petrology, vol. 96, no. 3-4, pp. 129-140, 2009.

[11] R. Thomas, P. Davidson, and H. Beurlen, "Tantalite-(Mn) from the Borborema Pegmatite Province, northeastern Brazil: Conditions of formation and melt- and fluid-inclusion constraints on experimental studies," Mineralium Deposita, vol. 46, no. 7, pp. 749-759, 2011.

[12] W. B. Simmons and K. L. Webber, "Pegmatite genesis: State of the art," European Journal of Mineralogy, vol. 20, no. 4, pp. 421438, 2008.

[13] D. London, "Melt boundary layers and the growth of pegmatitic textures," Canadian Mineralogist, vol. 37, pp. 826-827, 1999.

[14] D. London, "Granitic pegmatites: An assessment of current concepts and directions for the future," Lithos, vol. 80, no. 1-4, pp. 281-303, 2005.

[15] D. London, Pegmatites. Canadian Mineralogist, Special Publication 10, Mineralogical Association of Canada, Québec, Canada, 2008.

[16] D. London, "A petrologic assessment of internal zonation in granitic pegmatites," Lithos, vol. 184-187, pp. 74-104, 2014.

[17] D. London, "Reply to Thomas and Davidson on "A petrologic assessment of internal zonation in granitic pegmatites", "Lithos, vol. 212-215, pp. 469-484, 2015.

[18] R. Thomas, J. D. Webster, and W. Heinrich, "Melt inclusions in pegmatite quartz: Complete miscibility between silicate melts and hydrous fluids at low pressure," Contributions to Mineralogy and Petrology, vol. 139, no. 4, pp. 394-401, 2000.

[19] R. Thomas, J. D. Webster, and P. Davidson, "Understanding pegmatite formation: the melt inclusion approach," in Melt Inclusions in Plutonic Rocks, J. D. Webster, Ed., pp. 189-210, Mineralogical Association of Canada, Short Course 36, Québec, Canada, 2006.

[20] R. Thomas, J. D. Webster, and P. Davidson, "Be-daughter minerals in fluid and melt inclusions: Implications for the enrichment of Be in granite-pegmatite systems," Contributions to Mineralogy and Petrology, vol. 161, no. 3, pp. 483-495, 2011.

[21] A. J. Anderson, A. H. Clark, and S. Gray, "The occurrence and origin of zabuyelite (Li2CO3) in spodumene-hosted fluid inclusions: Implications for the internal evolution of rare-element granitic pegmatites," The Canadian Mineralogist, vol. 39, no. 6, pp. 1513-1527, 2001.

[22] A. J. Anderson, "Are silicate-rich inclusions in spodumene crystallized aliquots of boundary layer melt?” Geofluids, vol. 13, no. 4, pp. 460-466, 2013. 
[23] S. E. Kesler, P. W. Gruber, P. A. Medina, G. A. Keoleian, M. P. Everson, and T. J. Wallington, "Global lithium resources: relative importance of pegmatite, brine and other deposits," Ore Geology Reviews, vol. 48, pp. 55-69, 2012.

[24] A. J. Anderson, P. R. Meredith, W. A. Bassett, R. A. Mayanovic, and C. Benmore, "The design and application of a new Bassetttype diamond anvil cell for spectroscopic analysis of supercritical aqueous solutions," in Proceedings of the CNS 2nd CanadaChina Joint Workshop on Super Critical Water-Cooled Reactors (SCWR), 2010.

[25] J. Li, I.-M. Chou, S. Yuan, and R. C. Burruss, "Observations on the crystallization of spodumene from aqueous solutions in a hydrothermal diamond-anvil cell," Geofluids, vol. 13, no. 4, pp. 467-474, 2013.

[26] D. London, "Experimental phase equilibria in the system LiAlSiO ${ }_{4}-\mathrm{SiO}_{2}-\mathrm{H}_{2} \mathrm{O}$ : a petrogenetic grid for lithium rich pegmatites," American Mineralogist, vol. 69, no. 11-12, pp. 995-1004, 1984.

[27] Z. Zhang and Z. Duan, "Prediction of the PVT properties of water over wide range of temperatures and pressures from molecular dynamics simulation," Physics of the Earth and Planetary Interiors, vol. 149, no. 3-4, pp. 335-354, 2005.

[28] L. Haar, J. S. Gallagher, and G. S. Kell, NBS, AIRC Steam Tables: Thermodynamic and Transport Properties and Computer Programs for Vapor and Liquid States of Water in SI Units, Hemisphere, Washington, DC, USA, 1984.

[29] I.-M. Chou and S. H. Li, "Raman spectroscopic investigation of p-ßquartz phase transition in hydrothermal diamond-anvil cell and acquisition of equation of states of aqueous solutions," in Proceedings of the JpGU-AGU Joint Meeting 2017, Makuhari Messe, Chiba, Japan, May 2017.

[30] J. Li and I.-M. Chou, "An occurrence of metastable cristobalite in spodumene-hosted crystal-rich inclusions from Jiajika pegmatite deposit, China," Journal of Geochemical Exploration, vol. 171, pp. 29-36, 2016.

[31] C. Schmidt, I.-M. Chou, R. Bodnar, and W. A. Bassett, "Microthermometric analysis of synthetic fluid inclusions in the hydrothermal diamond-anvil cell," American Mineralogist, vol. 83, no. 9-10, pp. 995-1007, 1998.

[32] R. S. Darling and W. A. Bassett, "Analysis of natural $\mathrm{H} 2 \mathrm{O}+\mathrm{CO} 2$ $+\mathrm{NaCl}$ fluid inclusions in the hydrothermal diamond anvil cell," American Mineralogist, vol. 87, no. 1, pp. 69-78, 2002.

[33] W. A. Bassett, A. H. Shen, M. Bucknum, and I.-M. Chou, "A new diamond anvil cell for hydrothermal studies to $2.5 \mathrm{GPa}$ and from -190 to $1200^{\circ}$ C, Review of Scientific Instruments, vol. 64 , no. 8 , pp. 2340-2345, 1993.

[34] J. J. Student and R. J. Bodnar, "Synthetic fluid inclusions XIV: Coexisting silicate melt and aqueous fluid inclusions in the Haplogranite-H2O-NaCl-KCl system," Journal of Petrology, vol. 40, no. 10, pp. 1509-1525, 1999.

[35] M. J. Severs, T. Azbej, J. B. Thomas, C. W. Mandeville, and R. J. Bodnar, "Experimental determination of $\mathrm{H} 2 \mathrm{O}$ loss from melt inclusions during laboratory heating: Evidence from Raman spectroscopy," Chemical Geology, vol. 237, no. 3-4, pp. 358-371, 2007.

[36] P. I. Nabelek, A. G. Whittington, and M.-L. C. Sirbescu, "The role of $\mathrm{H} 2 \mathrm{O}$ in rapid emplacement and crystallization of granite pegmatites: Resolving the paradox of large crystals in highly undercooled melts," Contributions to Mineralogy and Petrology, vol. 160, no. 3, pp. 313-325, 2010.

[37] J. F. Schairer and N. L. Bowen, "The system $\mathrm{Na}_{2} \mathrm{O}-\mathrm{Al}_{2} \mathrm{O}_{3}-\mathrm{SiO}_{2}$," American Journal of Science, vol. 254, no. 3, pp. 129-195, 1956.
[38] R. S. Darling, I.-M. Chou, and R. J. Bodnar, "An occurrence of metastable cristobalite in high-pressure garnet Granulite," Science, vol. 276, no. 5309, pp. 91-93, 1997.

[39] D. A. Mustart, Phase relations in the peralkaline portion of the system $\mathrm{Na}_{2} \mathrm{O}-\mathrm{Al}_{2} \mathrm{O}_{3}-\mathrm{SiO}_{2}-\mathrm{H}_{2} \mathrm{O}$ [Ph.D. Diss.], Stanford University, 1972.

[40] R. Thomas and P. Davidson, "Water and melt/melt immiscibility, the essential components in the formation of pegmatites: evidence from melt inclusions," Zeitschrift für Geologische Wissenschaften, vol. 36, pp. 347-364, 2008.

[41] C. Schmidt, "Raman spectroscopic determination of carbon speciation and quartz solubility in $\mathrm{H}_{2} \mathrm{O}+\mathrm{Na}_{2} \mathrm{CO}_{3}$ and $\mathrm{H}_{2} \mathrm{O}$ $+\mathrm{NaHCO}_{3}$ fluids to $600{ }^{\circ} \mathrm{C}$ and $1.53 \mathrm{GPa}$," Geochimica et Cosmochimica Acta, vol. 145, pp. 281-296, 2014.

[42] S. Z. Smirnov, V. G. Thomas, V. S. Kamenetsky, O. A. Kozmenko, and R. R. Large, "Hydrosilicate liquids in the system $\mathrm{Na} 2 \mathrm{O}-\mathrm{SiO}$ 2- $\mathrm{H} 2 \mathrm{O}$ with $\mathrm{NaF}, \mathrm{NaCl}$ and Ta: Evaluation of their role in ore and mineral formation at high T and P," Petrology, vol. 20, no. 3, pp. 271-285, 2012.

[43] V. G. Thomas, S. Z. Smirnov, O. A. Kozmenko, V. A. Drebushchak, and V. S. Kamenetsky, "Formation and properties of hydrosilicate liquids in the systems $\mathrm{Na}_{2} \mathrm{O}-\mathrm{Al}_{2} \mathrm{O}_{3}-\mathrm{SiO}_{2}-\mathrm{H}_{2} \mathrm{O}$ and granite $-\mathrm{Na}_{2} \mathrm{O}-\mathrm{SiO}_{2}-\mathrm{H}_{2} \mathrm{O}$ at $600 \circ \mathrm{C}$ and 1.5 kbar," Petrology, vol. 22, no. 3, pp. 293-309, 2014. 

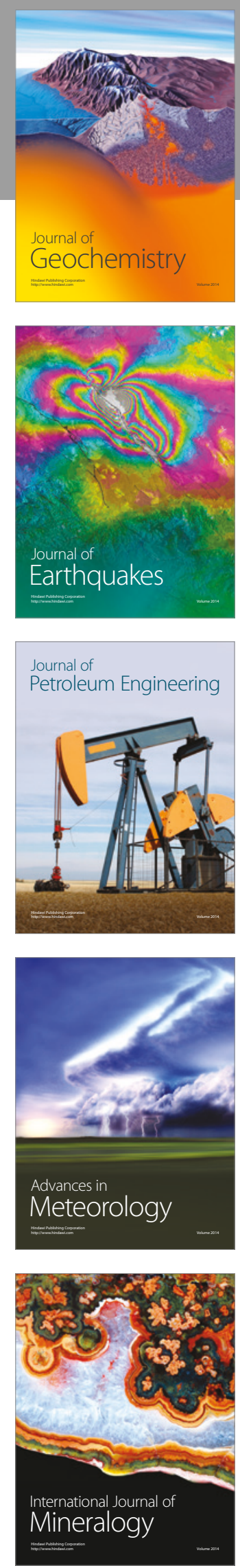
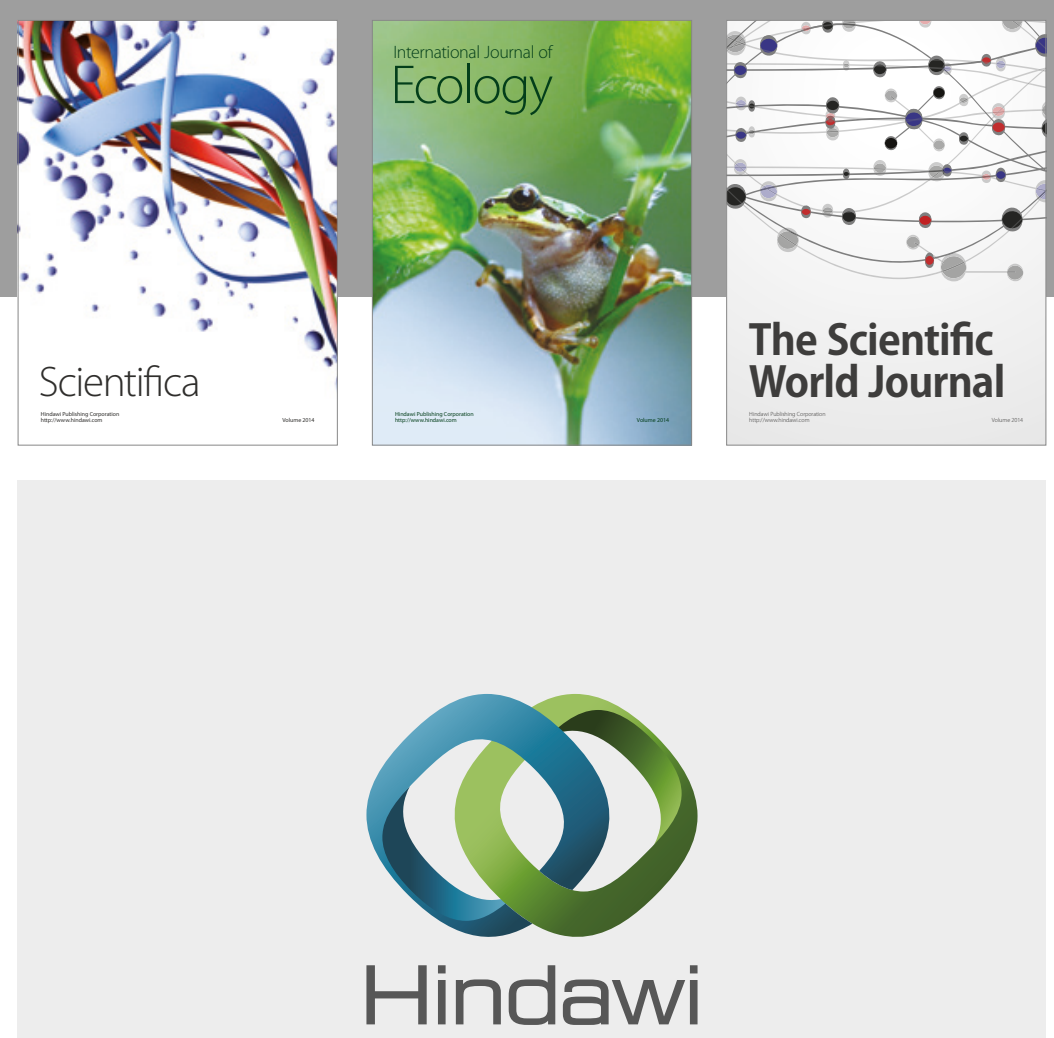

Submit your manuscripts at

https://www.hindawi.com
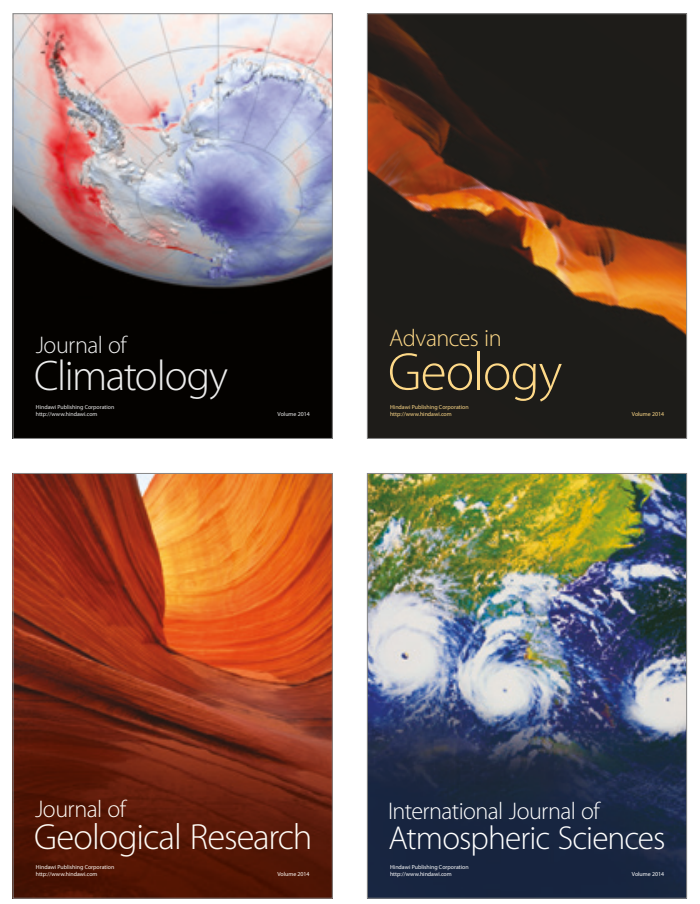

The Scientific

World Journal
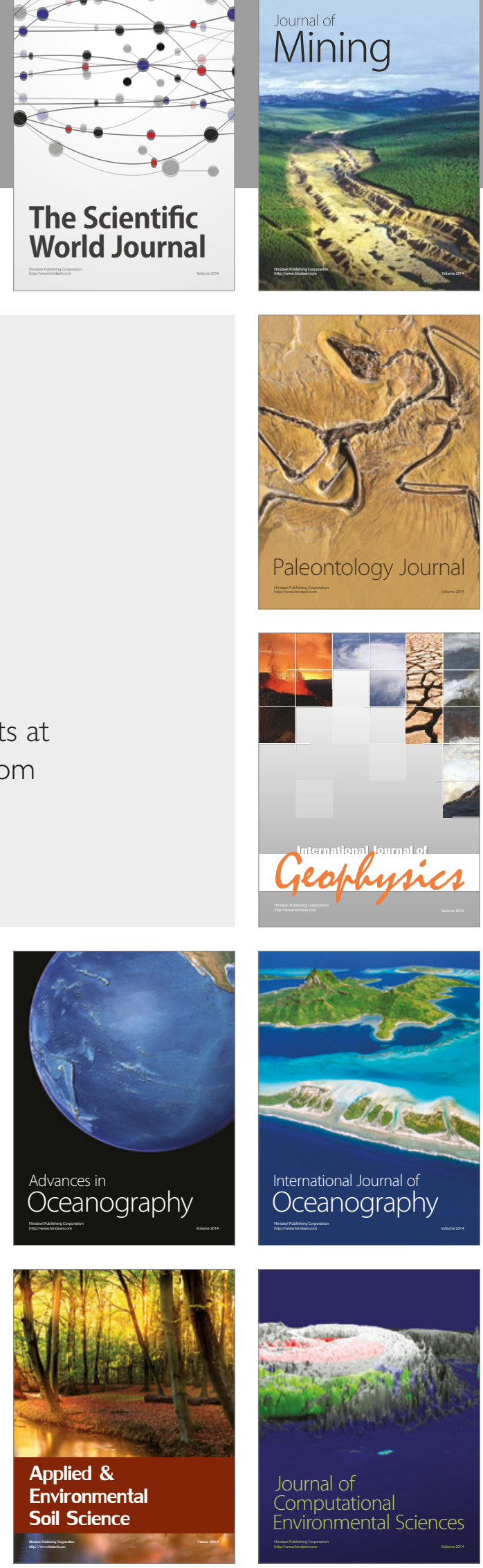